\title{
The Study of Consequences of Acceptance Technology When It Is Mandatory: A Conceptual Framework
}

\author{
Alireza Parvari ${ }^{1}$, Nur Naha binti Abu Mansor ${ }^{1}$, Masoomeh Jafarpoor ${ }^{1} \&$ Hamidreza Salehi ${ }^{1}$ \\ ${ }^{1}$ Department of Human Resource Development, Universiti Teknologi Malaysia, Skudai, Malaysia \\ Correspondence: Alireza Parvari, Department of Human Resource Development, Faculty of Management, \\ Universiti Teknologi Malaysia, 81310 Skudai, Malaysia. E-mail: Alirezaparvari@yahoo.com
}

Received: October 5, 2014 Accepted: October 31, 2014 Online Published: November 15, 2014

doi:10.5539/res.v6n4p209 URL: http://dx.doi.org/10.5539/res.v6n4p209

\begin{abstract}
While appearance of the technology can help employees and organizations achieve the optimized performance, it may have some negative consequences if it is not accepted by employees. Previous studies found some unintended consequences due to system rejection or acceptance by employees including job satisfaction and turnover intention. This paper finds other consequences including psychological contract, organizational commitment and turnover intention and then provides a conceptual framework.
\end{abstract}

Keywords: IT acceptance, TAM, psychological contract, organizational commitment, turnover intention

\section{Introduction}

Although development in technology has been used to help business processes, it may have some negative consequence if it is not accepted. Joshi and Lauer (1998) claimed that Information Technology or Systems (IT/IS) implementation may impact users' work environment in many different ways. Some of the impacts may be unfavorable for users, leading to negative consequences such as reduced job satisfaction, increased stress, and reduced commitment. It may also lead to sabotaging computer equipment, being absent or late to work, bad-mouthing the system, not using the new system and continuing to use the old system, and tampering with the data (Adams et al., 2004; Rivard \& Lapointe, 2012).

Previous studies also provide some evidence of the consequences of using information technology, individual's attitude and their behavior. For example Hussain and his colleagues (Chandio et al., 2013) examined the effect of perceived ease of use and perceived usefulness on behavioral intention. They reported significantly positive effect of perceived ease of use and perceived usefulness on behavioral intention. Chen (2010) also investigated the consequence of e-learning system use including overall job outcomes. However, these authors have considered only positive consequences of information system implementation. Meanwhile, they have failed to consider acceptance of information system and employees "attitude toward the organization" and job. Chen (2008) evaluated job satisfaction among information system personnel. He attempted to find the relationship between job characteristics of IS and job satisfaction. He reported a mutual relationship between them. However, he did not consider system characteristics and its acceptance by employees.

Among the available studies it seems that scholars have failed to provide comprehensive as well as theoretical evidence to be able to predict desirable and undesirable organizational behaviors of employees resulting from the acceptance of information technology. Among these studies, however, Maier and his colleagues (Maier et al., 2013) have considered information system acceptance and negative consequence of information system rejection although they also haven't considered psychological contract which is an antecedent for job satisfaction (e.g., Xiao \& Yan, 2010) in their study. They also have ignored investigating organizational commitment in their model which is an important variable for turnover intention (e.g., Mosadeghrad et al., 2008). Despite these related findings, no available studies have explored the effect of attitude toward using information system due to information system acceptance on turnover intention directly and through psychological contract and organizational commitment. In order to fill this gap this study attempts to provide a framework by considering the impact of technology acceptance on turnover intention directly as well as through psychological contract and organizational commitment. 


\section{Technology Acceptance Model}

The Technology Acceptance Model (TAM) is a core theoretical model in the information technology field that explains and predicts technology use (Cornell et al., 2011). The model suggests when individuals are voluntarily or involuntarily confronted with a new technology, a number of elements affect their choice about utilizing it. The goal of TAM is to predict information technology acceptance and identify design problems before users have experience with a system (Jahankhani et al., 2010). TAM predicts user acceptance of any technology determined by two factors: perceived ease of use and perceived usefulness. Consistent with technology acceptance model, perceived usefulness and perceived ease of use have a significant impact on a user's attitude toward using the system. TAM explains that individuals' perceptions are based on perceived usefulness (PU) and perceived ease of use (PEOU) which in turn, influences users' intention and usage behavior towards a particular information technology (Davis, 1989; Davis et al., 1989). Previous studies applying the TAM and its core constructs, PU and PEOU, proved its validity in predicting user acceptance behavior across technologies and contextual settings (Carayannis, 2013; Piaggesi et al., 2011).

\section{Psychological Contract}

Psychological contract is a predictor of turnover intention (Bal \& Kooij, 2011). Psychological contract refers to people's mental beliefs and expectation in relationship to their mental obligation in a contract relation between a person and another person such as employer (Leimeister, 2010). The psychological contract is generally defined in the academic literature as the implicit and explicit promises two parties make to one another (Wellin, 2012). The contract is termed psychological because it reflects each party's perceptions of the relationship and promises involved. A distinguishing feature between psychological contracts and legal contracts is that psychological contracts can be implicit (Cowling \& Mailer, 2013). Psychological contracts are violated more regularly during change processes, because perceived organizational obligations are fulfilled to a lesser extent during organizational transformations such as adoption of information technology (Cowling \& Mailer, 2013).

\section{Turnover Intention}

Tett and Meyer (1993) referred to turnover intentions as a conscious and deliberate willfulness to leave the organization. Turnover intention is described as a worker's plan of intent to leave the current work and looking into the future to find another job (Grigg, 2009). Intentions are the largest instantaneous determining factors of reality behavior. According to Price (1977) turnover can be separated in two components including voluntary and involuntary.

\section{Organizational Commitment}

Organizational commitment has been studied extensively by several researchers, and has been the subject of numerous critical reviews in recent years (Grigg, 2009; Locke, 2011; Pitt, 2009, Anvari et al., 2014). Organizational commitment has appeared as a centralized concept in the research of work attitudes and behavior (Meyer et al., 2002). This is due in large part to the demonstrated relations between organizational commitment and two variables of considerable significance to the study of vocational behavior: intentions to leave and actual turnover (Allen \& Meyer, 1996).

\section{A Conceptual Model Development}

The researches based on the Technology Acceptance Model (TAM \& Davis, 1989; Davis et al., 1989), provide empirical evidence that an individual's beliefs about an information system and attitude toward using it influence the intent to use the system and consequently the respective usage behavior (Davis, 1989). These relationships have been evaluated and discussed extensively in several studies (Williams et al., 2009). However, it is claimed that this does not hold true for predicting employees' usage behavior in organizations, especially when use is mandatory (Brown et al., 2002; Teo, 2011). In addition, the investigation of "outcomes in technology adoption research is very limited" (Topi \& Tucker, 2014; Venkatesh et al., 2007, p. 277). In particular, the consequences of employees' negative attitudes toward an information system remain unexplored. This is more precisely stated by Brown et al. (2002), who asked "if an employee's attitude is not related to his/her intention to use technology, what does it influence?" (p. 293) and subsequently suggest that "attitudes can have a significant influence on an individual's perception of the work environment and organization" (p. 291).

\subsection{The Relationship between ATU and PC}

As an organization introduces an information technology, each employee who works with the technology evaluates the technology, for example, in terms of its usefulness and ease of use (Davis et al., 1989). If employees do not evaluate the system as useful and easy to use, especially when they do not have the necessary skill to operate it or even if they don't know full potential of that information technology and are not even aware 
of all of its possibilities, they may evaluate the system rather negatively.

There are many reasons why employees may wish to breach the psychological contract during information technology implementation. For example, employees with poor communication skills may feel that an information technology is being implemented to reduce costs rather than to facilitate work (Stone \& Lukaszewski, 2009; Anvari \& Atiyaye, 2014; Anvari et al., 2014). This assumption is in line with Ferratt et al (2005), who indicate that employees prefer employer organizations that support human capital over task- and profit-oriented organizations. However perceived organizational support as a mediator of the relations between individual differences and psychological contract breach shows that it has an effect on psychological contract (Suazo \& Turnley, 2010). Information technology also may create additional work and stress if it is difficult to use if too many clicks are required or if it requires too much time. Thus the employees may feel that they have additional work to do and it is not fair that they are taken away from what they see as their main job responsibility. As a result, it may affect employee perceptions of the organization and consequently, they may perceive a breach of the psychological contract as fairness forms psychological contract (Noblet et al., 2009). Moreover, recent research demonstrates that employees are critical of having to wait while opening attachments and manual data entry of incoming paper-based applications are viewed as a disruption of their daily work routines (Maier et al., 2013; Anvari et al., 2013). In the same way, all mentioned reasons can change employee perceptions toward their organization as employees feel that they are not supported by the organization as the organization has provided such a system. However, employees' perceived organizational support can affect psychological contract.

\subsection{The Relationship between PC and TI}

Behavior and attitudes are influenced quite significantly by an individual's perception of his obligations and perceptions of how well the other party's obligations have been fulfilled (Morrison \& Robinson, 2004). The lack of fulfillment of aspects of the psychological contract will lead to a breach of the contract, with a change in attitudes and of behavior as a consequence (Morrison \& Robinson, 2004; Rousseau, 1989). Rousseau (1989) suggests that a breach of the psychological contract may lead to strong emotional reactions such as anger, resentment and a sense of injustice. Regarding behavior, Robinson and Rousseau (2000) conducted a research study in which they found that breach of psychological contract may lead to an increase in employee turnover. As such, the notion of a psychological contract provides a framework within which behavior and employee attitudes, such as the intention to leave an organization, can be researched and interpreted (Hancer \& George, 2003).

\subsection{The Relationship between $P C$ and $O C$}

Researchers have described a psychological contract as having implicit expectations and which usually occur when an individual perceives that their contribution will be reciprocated in the future. Furthermore, (Schein, 1980) took a similar approach and defined a psychological contract as a set of unwritten expectations and obligations which were significant determinants of behavior at the individual and organizational levels. The investigation into the relationship between employee-employer suggests that employees who maintain a positive psychological contract in their organization have positive outcomes for themselves and their employers. Indeed, a high-quality exchange relationship is positively related to employees' organizational commitment levels, and they are likely to reciprocate the feeling to an even greater degree (Farndale et al., 2011). As a result, social exchange theory suggests that psychological contracts have a direct relationship with organizational commitment. This relationship is supported by many researches (Ali et al., 2010; Behery et al., 2012; Sturges et al., 2005).

\subsection{The Relationship between $O C$ and TI}

The best predictors of turnover intention are professional commitment and organizational commitment (Barak et al., 2001). One of the most predominate associations to organizational commitment is its effect on decreased intent to quit. Indeed, several studies of turnover intention have substantiated that it occurs as an outcome of organizational commitment (Carayon et al., 2006).

There are studies that have examined the relationship between organizational commitment and turnover intention. Moreover, they reported a negative relationship between two variables (Parker et al., 2003; Siong et al., 2006). In a meta-analysis of two hundred commitment studies, Mathieu and Zajac (1990) supported the insight of Mowday et al. (1982) that organizational commitment has a negative relationship with turnover intention. Moreover, this study results also show that an employee who is committed to an organization is more likely to stay in his or her job. Similarly, Tett and Meyer (1993) conducted a meta-analysis of one hundred fifty five studies comprised of one hundred seventy eight independent samples; the researchers found that organizational commitment is a predictor of intention to leave. 


\section{The Conceptual Framework}

The independent and dependent variables are developed based on literature review. By considering technology evaluation this paper utilizes Technology Acceptance Model featuring ease of use, perceived usefulness and attitude toward using the system. Attitude toward using the system can also lead to work related outcomes including psychological contract, turnover intention and organizational commitment. The conceptual framework is shown in Figure 1.

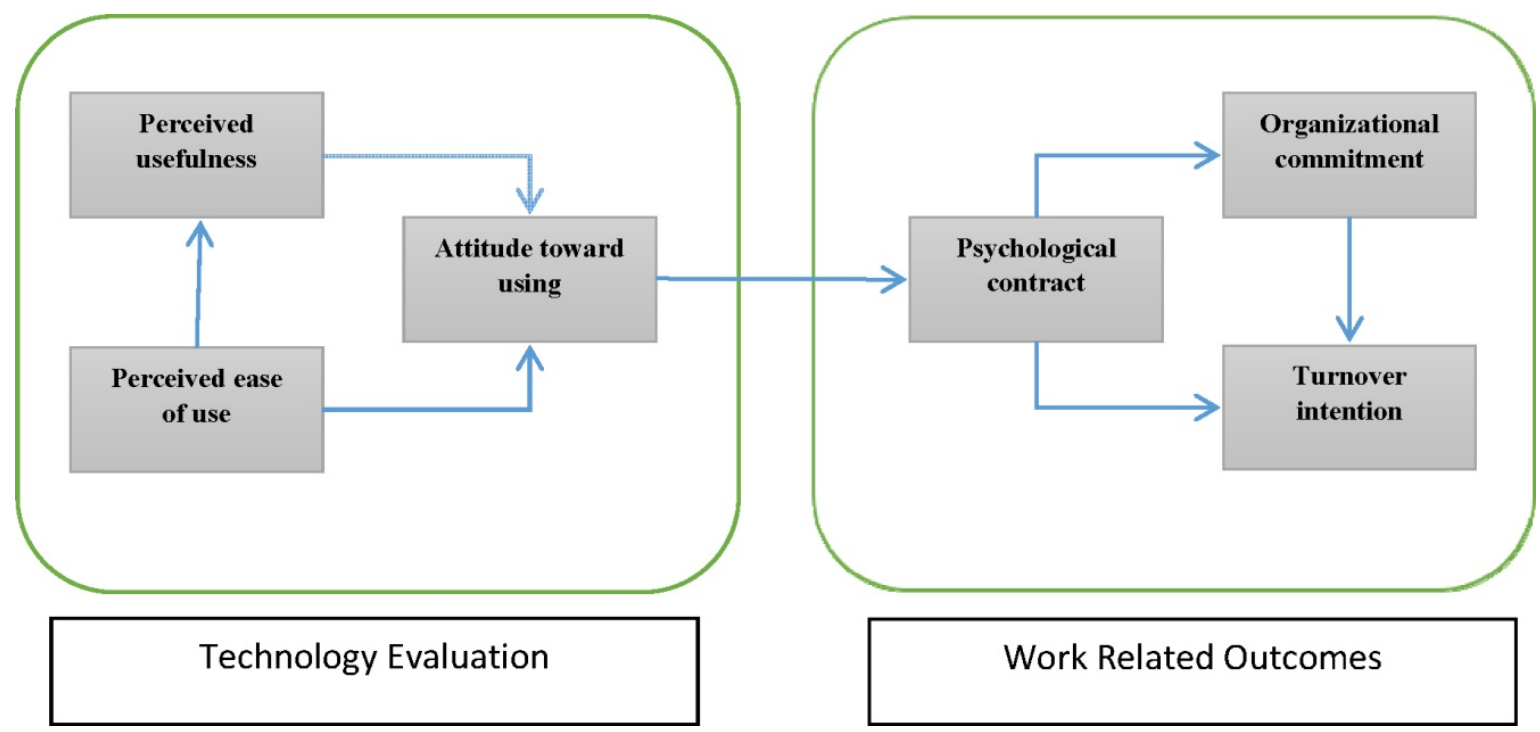

Figure 1. Conceptual framework

\section{References}

Adams, B., Berner, E. S., \& Wyatt, J. R. (2004). Applying strategies to overcome user resistance in a group of clinical managers to a business software application: A case study. Journal of Organizational and End User Computing (JOEUC), 16(4), 55-64. http://dx.doi.org/10.4018/joeuc.2004100104

Ali, A., Haq, I. U., Ramay, M. I., \& Azeem, M. U. (2010). The Impact of Psychological Contract on Affective Commitment. Interdisciplinary Journal of Contemporary Research In Business, 2(7), 239.

Allen, N. J., \& Meyer, J. P. (1996). Affective, continuance, and normative commitment to the organization: An examination of construct validity. Journal of vocational behavior, 49(3), 252-276. http://dx.doi.org/10.1006/jvbe.1996.0043

Anvari, R., Huzaid, N. S. B. J., Miri, S. A., \& Chermahini, S. H. (2013). Mediating effect of psychological contract in the relationship between learning and development initiatives and engineers' intention to stay. Review of European Studies, 5(5), 233-237. http://dx.doi.org/10.5539/res.v5n5p233

Anvari, R., Irum, S., Shah, I. M., Mahmoodzadeh, N., \& Ashfaq, M. (2014). Determinants of information technology leadership program. Review of European Studies, 6(2), 45-49. http://dx.doi.org/10.5539/res.v6n2p45

Anvari, R., \& Atiyaye, D. M. (2014). Determinants of effective communication among undergraduate students. International Education Studies, 7(9), 112-121. http://dx.doi.org/10.5539/ies.v7n9p112

Anvari, R., Irum, S., Ashfaq, M., \& Atiyaye, D. M. (2014). The impact of leader's cultural intelligence on organizational commitment. Asian Social Science, 10(17), 45-51. http://dx.doi.org/10.5539/ass.v10n17p45

Bal, P. M., \& Kooij, D. (2011). The relations between work centrality, psychological contracts, and job attitudes: The influence of age. European Journal of Work and Organizational Psychology, 20(4), 497-523. http://dx.doi.org/10.1080/13594321003669079

Barak, M. E. M., Nissly, J. A., \& Levin, A. (2001). Antecedents to retention and turnover among child welfare, social work, and other human service employees: What can we learn from past research? A review and metanalysis. Social service review, 75(4), 625-661. http://dx.doi.org/10.1086/323166 
Behery, M., Paton, R., \& Hussain, R. (2012). Psychological contract and organizational commitment: The mediating effect of transformational leadership. Competitiveness Review, 22(4), 299-319. http://dx.doi.org/10.1108/10595421211247141

Brown, S. A., Massey, A. P., Montoya-Weiss, M. M., \& Burkman, J. R. (2002). Do I really have to? User acceptance of mandated technology. European journal of information systems, 11(4), 283-295. http://dx.doi.org/10.1057/palgrave.ejis.3000438

Carayannis, E. G. (2013). Creating a Sustainable Social Ecology Using Technology-driven Solutions. Information Science Reference. http://dx.doi.org/10.4018/978-1-4666-3613-2

Carayon, P., Schoepke, J., Hoonakker, P., Haims, M. C., \& Brunette, M. (2006). Evaluating causes and consequences of turnover intention among IT workers: The development of a questionnaire survey. Behaviour \& Information Technology, 25(5), 381-397. http://dx.doi.org/10.1080/01449290500102144

Chen, H.-J. (2010). Linking employees'e-learning system use to their overall job outcomes: An empirical study based on the IS success model. Computers \& Education, 55(4), 1628-1639. http://dx.doi.org/10.1016/j.compedu.2010.07.005

Chen, L.-H. (2008). Job satisfaction among information system (IS) personnel. Computers in Human Behavior, 24(1), 105-118. http://dx.doi.org/10.1016/j.chb.2007.01.012

Cornell, R. M., Eining, M. M., \& Hu, P. J.-H. (2011). The effects of process accountability on individuals' use of a familiar technology. Journal of Information Systems, 25(1), 109-128. http://dx.doi.org/10.2308/jis.2011.25.1.109

Cowling, A., \& Mailer, C. (2013). Managing Human Resources. Taylor \& Francis.

Davis, F. D. (1989). Perceived usefulness, perceived ease of use, and user acceptance of information technology. MIS quarterly, 319-340. http://dx.doi.org/10.2307/249008

Davis, F. D., Bagozzi, R. P., \& Warshaw, P. R. (1989). User acceptance of computer technology: A comparison of two theoretical models. Management science, 35(8), 982-1003. http://dx.doi.org/10.1287/mnsc.35.8.982

Farndale, E., Van Ruiten, J., Kelliher, C., \& Hope-Hailey, V. (2011). The influence of perceived employee voice on organizational commitment: An exchange perspective. Human Resource Management, 50(1), 113-129. http://dx.doi.org/10.1002/hrm.20404

Ferratt, T. W., Agarwal, R., Brown, C. V., \& Moore, J. E. (2005). IT human resource management configurations and IT turnover: Theoretical synthesis and empirical analysis. Information systems research, 16(3), 237-255. http://dx.doi.org/10.1287/isre.1050.0057

Grigg, S. H. (2009). The impact of job satisfaction, organizational commitment, and intent to leave on employee retention: An investigation within the child care industry. CAPELLA UNIVERSITY.

Hancer, M., \& George, R. T. (2003). Psychological empowerment of non-supervisory employees working in full-service restaurants. International Journal of Hospitality Management, 22(1), 3-16. http://dx.doi.org/10.1016/S0278-4319(02)00032-4

Hussain Chandio, F., Irani, Z., Abbasi, M. S., \& Nizamani, H. A. (2013). Acceptance of online banking information systems: An empirical case in a developing economy. Behaviour \& Information Technology, 32(7), 668-680. http://dx.doi.org/10.1080/0144929X.2013.806593

Jahankhani, H., Watson, D. L., Me, G., \& Leonhardt, F. (2010). Handbook of electronic security and digital forensics. World Scientific.

Joshi, D. K., \& Lauer, D. T. W. (1998). Impact of information technology on users' work environment: A case of computer aided design (CAD) system implementation. Information \& Management, 34(6), 349-360. http://dx.doi.org/10.1016/S0378-7206(98)00069-X

Leimeister, S. (2010). IT outsourcing governance: Client types and their management strategies. Springer. http://dx.doi.org/10.1007/978-3-8349-6303-1

Locke, E. (2011). Handbook of Principles of Organizational Behavior: Indispensable Knowledge for Evidence-Based Management. Wiley.

Maier, C., Laumer, S., Eckhardt, A., \& Weitzel, T. (2013). Analyzing the impact of HRIS implementations on HR personnel's job satisfaction and turnover intention. The Journal of Strategic Information Systems, 22(3), 193-207. http://dx.doi.org/10.1016/j.jsis.2012.09.001 
Mathieu, J. E., \& Zajac, D. M. (1990). A review and meta-analysis of the antecedents, correlates, and consequences of organizational commitment. Psychological bulletin, 108(2), 171. http://dx.doi.org/10.1037/0033-2909.108.2.171

Meyer, J. P., Stanley, D. J., Herscovitch, L., \& Topolnytsky, L. (2002). Affective, continuance, and normative commitment to the organization: A meta-analysis of antecedents, correlates, and consequences. Journal of vocational behavior, 61(1), 20-52. http://dx.doi.org/10.1006/jvbe.2001.1842

Morrison, E. W., \& Robinson, S. L. (2004). The employment relationship from two sides: Incongruence in employees' and employers' perceptions of obligations. The employment relationship: Examining psychological and contextual perspectives, 161-180.

Mosadeghrad, A. M., Ferlie, E., \& Rosenberg, D. (2008). A study of the relationship between job satisfaction, organizational commitment and turnover intention among hospital employees. Health Services Management Research, 21(4), 211-227. http://dx.doi.org/10.1258/hsmr.2007.007015

Mowday, R. T., Porter, L. W., \& Steers, R. M. (1982). Employee-organization linkages: The psychology of commitment, absenteeism, and turnover (vol. 153). Academic Press New York.

Noblet, A. J., Rodwell, J. J., \& Allisey, A. (2009). Police stress: The role of the psychological contract and perceptions of fairness. Policing: An International Journal of Police Strategies \& Management, 32(4), 613-630. http://dx.doi.org/10.1108/13639510911000731

Parker, C. P., Baltes, B. B., Young, S. A., Huff, J. W., Altmann, R. A., Lacost, H. A. et al. (2003). Relationships between psychological climate perceptions and work outcomes: a meta-analytic review. Journal of organizational Behavior, 24(4), 389-416. http://dx.doi.org/10.1002/job.198

Piaggesi, D., Castelnovo, W., \& Sund, K. J. (2011). Global Strategy and Practice of E-governance: Examples from Around the World. Information Science Reference. http://dx.doi.org/10.4018/978-1-60960-489-9

Pitt, J. S. (2009). Relationship between person-organization fit, job satisfaction, organizational commitment, and turnover intent among state vocational rehabilitation counselors. MICHIGAN STATE UNIVERSITY.

Price, J. L. (1977). The study of turnover (vol. 19771). Iowa State University Press Ames.

Rivard, S., \& Lapointe, L. (2012). Information Technology Implementers Responses to User Resistance: Nature and Effects. MIS quarterly, 36(3).

Robinson, S. L., \& Morrison, E. W. (2000). The development of psychological contract breach and violation: A longitudinal study. Journal of organizational Behavior, 21(5), 525-546. http://dx.doi.org/10.1002/1099-1379(200008)21:5<525::AID-JOB40>3.0.CO;2-T

Rousseau, D. M. (1989). Psychological and implied contracts in organizations. Employee responsibilities and rights journal, 2(2), 121-139. http://dx.doi.org/10.1007/BF01384942

Schein, E. (1980). Organizational psychology (3rd. ed.). Englewood Cliffs.

Siong, Z. M. B., Mellor, D., Moore, K. A., \& Firth, L. (2006). Predicting intention to quit in the call centre industry: Does the retail model fit? Journal of Managerial Psychology, 21(3), 231-243. http://dx.doi.org/10.1108/02683940610659579

Stone, D. L., \& Lukaszewski, K. M. (2009). An expanded model of the factors affecting the acceptance and effectiveness of electronic human resource management systems. Human resource management review, 19(2), 134-143. http://dx.doi.org/10.1016/j.hrmr.2008.11.003

Sturges, J., Conway, N., Guest, D., \& Liefooghe, A. (2005). Managing the career deal: The psychological contract as a framework for understanding career management, organizational commitment and work behavior. Journal of Organizational Behavior, 26(7), 821-838. http://dx.doi.org/10.1002/job.341

Suazo, M. M., \& Turnley, W. H. (2010). Perceived organizational support as a mediator of the relations between individual differences and psychological contract breach. Journal of Managerial Psychology, 25(6), 620-648. http://dx.doi.org/10.1108/02683941011056969

Teo, T. (2011). Technology Acceptance in Education. Sense Publishers. http://dx.doi.org/10.1007/978-94-6091-487-4

Tett, R. P., \& Meyer, J. P. (1993). Job satisfaction, organizational commitment, turnover intention, and turnover: Path analyses based on meta-analytic findings. Personnel psychology, 46(2), 259-293. http://dx.doi.org/10.1111/j.1744-6570.1993.tb00874.x 
Topi, H., \& Tucker, A. (2014). Computing Handbook, Third Edition: Information Systems and Information Technology. Taylor \& Francis.

Venkatesh, V., Davis, F. D., \& Morris, M. G. (2007). Dead or alive? The development, trajectory and future of technology adoption research. Association for Information Systems, 8(4), 268-284.

Wellin, M. (2012). Managing the Psychological Contract: Using the Personal Deal to Increase Business Performance. Ashgate Publishing, Limited.

Williams, M. D., Dwivedi, Y. K., Lal, B., \& Schwarz, A. (2009). Contemporary trends and issues in IT adoption and diffusion research. Journal of Information Technology, 24(1), 1-10. $\mathrm{http}: / / \mathrm{dx}$.doi.org/10.1057/jit.2008.30

Xiaoyan, Z., \& Yanping, L. (2010). A study on psychological contract, job satisfaction and turnover intention in banking industry. Information Science and Engineering (ICISE), 2010 2nd International Conference on. http://dx.doi.org/10.1109/ICISE.2010.5691029

\section{Copyrights}

Copyright for this article is retained by the authors, with first publication rights granted to the journal.

This is an open-access article distributed under the terms and conditions of the Creative Commons Attribution license (http://creativecommons.org/licenses/by/3.0/). 